\title{
Chronic Toxic Effect of Phenol on Zebrafish Branchydanio rerio
}

\author{
Hossein Razani, ${ }^{* 1}$ Kenji Nanba, ${ }^{* 2}$ and Shiro Murachi*2 \\ (Accepted March 10, 1986)
}

\begin{abstract}
Duplicated groups of 9 zebrafish, 3 fernales and 6 males, were exposed to 2.2, 4.9 and $24 \mathrm{ppm}$ phenol solutions for 3 months. The fish behaved abnormally at 4.9 and $24 \mathrm{ppm}$ almost immediately after placement in the test aquaria. The effect of phenol toxicity on the gill, ovary, kidney, intestine, and blood cells were studied carefully. The extent of damage of these organs and also the abnormal behavior were more severe at $24 \mathrm{ppm}$ than at $4.9 \mathrm{ppm}$. Histological pictures of the studied organs and behavior of the fish at $2.2 \mathrm{ppm}$ were almost similar to those at controls.

Most of the fish at $24 \mathrm{ppm}$ died within a few days, but some remained alive till the end of the experiment. However, no fish died at 4.9 and $2.2 \mathrm{ppm}$. The survived fish gradually recovered from the initial damage and showed improved condition till the end of the experiment.

None of the fish spawned at $24 \mathrm{ppm}$, though all the fish at 2.2 and $4.9 \mathrm{ppm}$ spawned frequently. The interval between spawnings were longer at 2.2 and $4.9 \mathrm{ppm}$ than at control groups.

The off-spring (eggs and larvae) of $4.9 \mathrm{ppm}$ which were cultured in the same concentration all died within 7-12 days. Whereas some of those transferred to the control water survived and were cultured for 2 months and grew successfully.

The off springs of $2.2 \mathrm{ppm}$ which were cultured in the same concentration and control water survived and grew at a rate almost equal to those of the control group.
\end{abstract}

Phenol in the environmental water are highly toxic to aquatic organisms. The international limit for phenol in water as defined by the World Health Organization (W.H.O) has been set at $1 \mu \mathrm{g} / L^{13}$ Sources of phenol pollution in fresh water include the cooking of coal, chemical plants, gas works and oil refineries, pesticide plants, wood preserving plants, and dye manufacturing plants. $^{2-8)}$

For a number of fishes the lethal concentration doses of phenol which cause $50 \%$ mortalities within $96 \mathrm{~h}\left(96 \mathrm{~h}-\mathrm{LC}_{\mathrm{8} 0}\right)$ have been determined. These doses differed greatly according to the subjected species. In rainbow trout it was about $4.2-5.0 \mathrm{ppm}_{2}{ }^{7}$ ) in Goldfish $44.5 \mathrm{ppm}_{2}{ }^{8)}$ and in zebrafish 24.9 ppm. $^{\text {.) }}$

In our previous paper, ${ }^{8)}$ we determined that phenol acts directly on the gills and cause hypoxia. Furthermore, it cause physiological damages to the kidney, liver and intestine. In the following study, the chronic toxic effect of phenol on behavioral, histological and hematological changes, spawning, and survival rate of eggs and larvae of zebrafish were explored. The purpose of the study was attained by culturing of the parental and off-springs of zebrafish in low concentration of phenol. Histological changes of liver, kidney, gill, intestine and ovary due to the toxic doses of phenol for zebrafish Branchydanio rerio were studied.

\section{Material and Methods}

\section{Experiment 1}

Two and half months old zebrafish were bought from a local fish dealer and kept in $30 l$ aquaria at $24^{\circ} \mathrm{C}$. They served as stock fish. They were used after 2 weeks acclimatization to the new environment. Experiment at the following concentrations were carried out in duplicate; control experimental water $(0 \mathrm{ppm}), 2.2,4.9$, and $24 \mathrm{ppm}$ phenol. Each duplicated concentration named as group A and group B. Each group consisted of 3 females and 6 males and were kept in $15 l$ aquarium. The fish varried in body weight from 0.25 to $0.31 \mathrm{~g}$ and in total body length from 1.3 to $3.3 \mathrm{~cm}$. This experiment was performed for 3

*1 Fisheries Department, The University of Tokyo, Bunkyo, Tokyo 113, Japan (ホセイン・ラザニ：東京 大学農学部).

*2 Faculty of Applied Biological Science, Hiroshima University, Midorimachi, Fukuyama 720, Japan (難波 萧二, 村地四郎：広島大学生物生産学部). 
months.

For the maintainance of constant phenol concentrations during the course of experiment the solutions were renewed once a day. Phenol concentrations were measured by Aminoantipyrine method, ${ }^{10)}$ prior to and immediately after each renewal. The fish were fed with Tetramine twice a day.

Behavioral changes and time of death of each fish were recorded. Death of the fish was determined by the cessation of gill movements and lack of response to mechanical stimulus.

Interval samplings were carried out on 1 male and 1 female of group A, 1 female and 1 male of group B, respectively after 1 and 2 months and the rest were sacrificed at the termination of the experiment.

\section{Experiment 2}

First breeding experiment. Two hundred eggs of the parental fish of the experiment one which were treated with control experimental water $(0$ ppm), 2.2, and $4.9 \mathrm{ppm}$ phenol concentrations were collected after 15 days treatments. Eggs from each concentration were divided into $A$ and B groups, 100 each, and then exposed to the same phenol concentration as their parents. No fish spawned at $24 \mathrm{ppm}$. This experiment was performed for two months.

Second breeding experiment. Three hundred eggs of the parental fish of the experiment one which were treated with 2.2 and $4.9 \mathrm{ppm}$ were collected after 30 days of treatments. Eggs of each concentration was divided into $\mathrm{A}, \mathrm{B}$ and $\mathrm{C}$ groups, 100 each. Group $A$ was exposed to the same phenol concentration as the parental fish. Groups B and C were washed twice with control water. Thereafter, group $B$ was replaced in its initial phenol concentration while group $\mathrm{C}$ was kept in control water $(0 \mathrm{ppm})$. Control groups were made by collecting 200 eggs of the parents which were kept in the control water of experiment one. These eggs were divided into two groups, 100 each. One group was washed with control water and the other one was not. Both were kept in control water. This experiment was carried out for 2 months.

To verify whether any phenol remained on the membrane of eggs after washing by control water, 10 eggs were washed and checked by Aminoantipyrine method. ${ }^{10)}$ No phenol was detected.

In the first and second breedings, prior to hatch the phenol solutions were changed every $24 \mathrm{~h}$ and the non-vital eggs were simultaneously separated. From hatch to post-larvae stage, the solutions were changed every $48 \mathrm{~h}$ to reduce stress on newly hatched larvae. When all the larvae started to swim freely and were capable of taking artificial foods (after 4 days), the solution was changed every $36 \mathrm{~h}$. After 10 days, the solution was changed every $24 \mathrm{~h}$. In the first 10 days $2 l$ and thereafter $15 l$ capacity aquaria were used.

The larvae were fed two days after hatch when the yolk sac had not yet been completely absorbed. The diet was consisted of Tetramine and rainbow trout pellets made into solution and given to them twice a day. In addition boiled egg's yolk was also solved and given once a day. After 15 days, only Tetramine was given twice a day.

In all the experiments dechlorinated tap water was used. Water hardness (measured as $\mathrm{CaCO}_{3}$ ), D.O., and $\mathrm{pH}$ were $57-61 \mathrm{ppm}, 6.4-8.5 \mathrm{ppm}$, and $6.1-6.5$, respectively. The water temperature was controlled thermostatically and kept at $24 \pm 1^{\circ} \mathrm{C}$. Histologically, the gills, liver, kidney, intestine were stained with hematoxylin and Eosin $(\mathrm{H}-\mathrm{E})$, and hematologically the blood cells were stained with May Grünwald Geimsa. The methods of these studies were the same as explained in our previous paper. ${ }^{\text {) }}$

\section{Results}

\section{Experiment 1}

Histological pictures of gill, liver, kidney, intestine, and hematological features of blood cells are shown in Figs. 1-8. Behavioral, histological, and hematological changes of zebra fish treated with phenol are as follows.

A) $24 \mathrm{ppm}$ phenol concentration. During the course of experiment, the phenol concentration ranged from 22 to $26 \mathrm{ppm}$ immediately after renewing and 19 to $22 \mathrm{ppm}$ prior to renewing.

The fish were affected immediately after placing at $24 \mathrm{ppm}$ phenol solution. They lost their balance, swam wildly up and down, and the movements of the mouth and gills opercles were violent. The majority of the fish permanently lost their balances and then death occurred within a few days, In these fish the gill, kidney, liver, intestine and blood cells were severly damaged as were explained in detail in our previous paper."

During this exposure, only 3 out of 9 fish from each duplicated phenol concentration survived. Abnormal behaviors of these fish gradually diminished (visible for about $10 \mathrm{~min}$, only at the time 


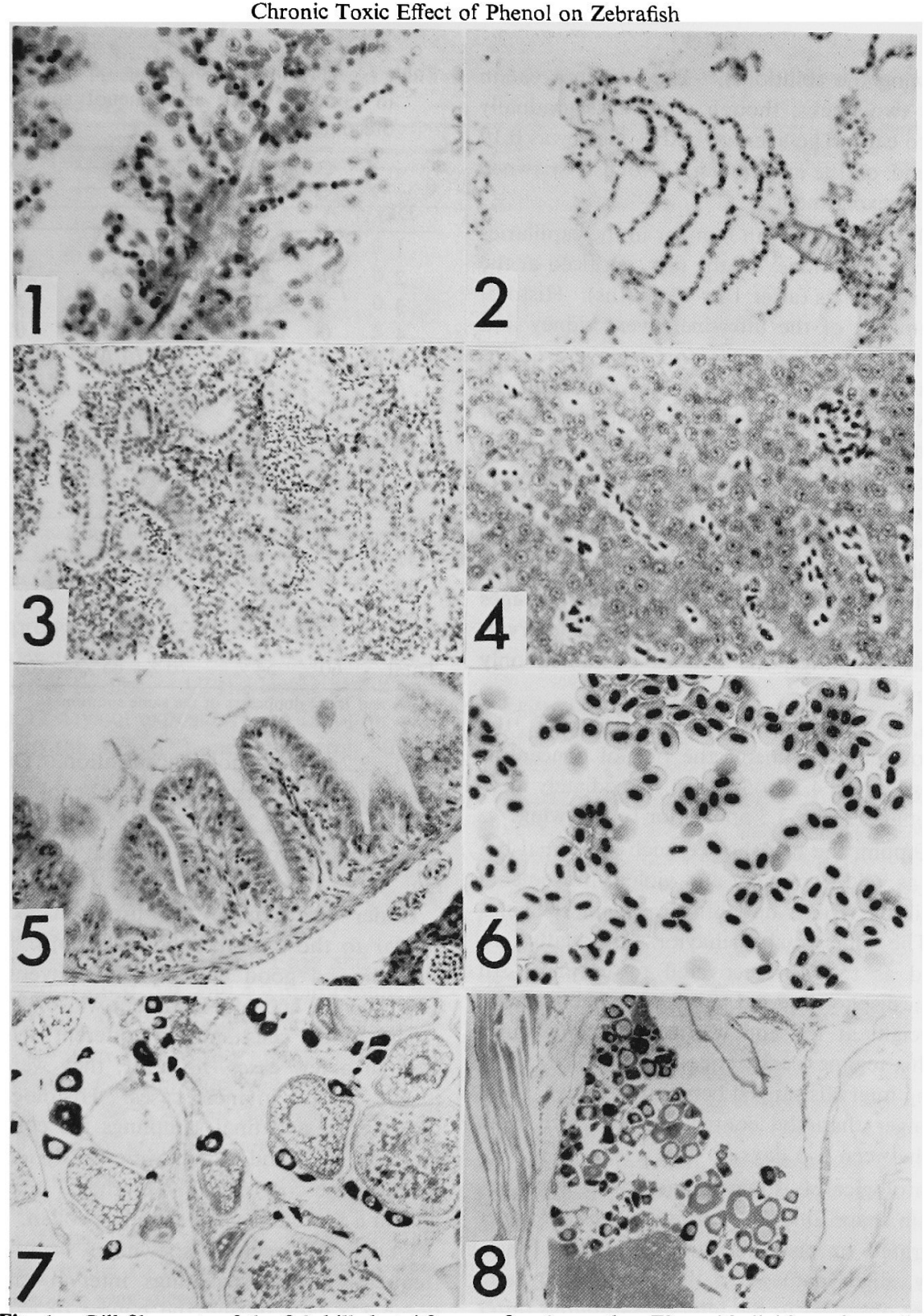

Fig. 1. Gill filaments of the fish killed at $4.9 \mathrm{ppm}$ after 1 month. The epithelial layer is swollen and the epithelial cells are far from the pillar cells. Stained with Hematoxylin-Eosin (H-E), $\times 250$.

Fig. 2. Gill filaments of the fish killed by exposure to $24 \mathrm{ppm}$ after $29 \mathrm{~h}$. The epithelial layer is stripped away, only the pillar cells remained. H-E. $\times 250$

Fig. 3. Kidney of the fish killed by exposure to 24 ppm after $48 \mathrm{~h}$. Necrosis of nephrons and agglutination of blood cells has occurred. H-E, $\times 500$.

Fig. 4. Liver cells of the fish killed at $4.9 \mathrm{ppm}$ after 1 month. Extravasation of blood vessels has occurred. H-E, $\times 500$.

Fig. 5. Intestine of the fish killed at $24 \mathrm{ppm}$ after 3 months. The Lamina propria became scanty and the goblet cells are few in number. H-E, $\times 500$.

Fig. 6. Red blood cells of the fish killed by exposure to $24 \mathrm{ppm}$ after $62 \mathrm{~h}$. The cells membranes are partially or completely removed and many ghosts are present. Stained with MayGrunwald-Geimsa, $\times 250$.

Fig. 7. Ovary of the fish killed at $4.9 \mathrm{ppm}$ after 2 months. Some oocytes are under atretia. H-E, $\times 250$.

Fig. 8. Ovary of the fish killed at $24 \mathrm{ppm}$ after 3 months. Ovary contained only immature oocytes. H-E, $\times 250$. 
of renewing the solutions). They did not eat in the first two weeks, though afterwards gradually started to eat. The average body weight was 0.19 at the end of the experiment. No fish spawned during the experiment.

Blood cells were few in number in the capillaries of the liver and kidney of the fish sacrificed at the interval samplings (after 1 or 2 months). Histological damages of the intestine, liver, kidney and gills of the fish in interval samplings were not as acute as those of which died due to phenol in the first few days. The number of disintegrated or pre-disintegrating blood cells were few in number. The last fish of each duplicated group which were killed at the termination showed even better conditions. In these fish, the blood cells inside the capillaries of the liver or kidney were almost identical to those of the controls and the damages to other organs were also slight. At the intervals and final samplings, the ovaries contained only immature oocyts.

B) $4.9 \mathrm{ppm}$ phenol solution. During the course of the experiment, the phenol concentration ranged from 4.2 to $5.2 \mathrm{ppm}$ immediately after renewing and 2.0 to $3.5 \mathrm{ppm}$ prior to renewing.

At $4.9 \mathrm{ppm}$, the fish showed such abnormal behaviors as wild swimming and violent movements of the gill operculars only after renewing the solution. The abnormal behaviors gradually diminished as the fish recovered to normal. All of them displayed good appetite. The average body weight at the end was $0.29 \mathrm{~g}$. Spawnings under this regime were frequently observed. The spawning intervals ranged between 49 days, those were longer than the control group which were ranged between $2-5$ days.

Hematologically, some blood cells were abnormal in shape and size, and a few were in either disintegrated or pre-disintegrating stage. Histologically, slight damage to the liver, kidney and gills were observed in the interval samplings (after 1 or 2 months). The blood vessels in both kidney and liver were compacted with blood cells. The epithelial layers of gill filament and secondary gill filament were swollen and the epithelial cells were arranged in outer parts. The intestine did not show any sign of damages for the most parts, though in a few cases the epithelial layer were slightly infiamed. At the termination, the above described damages were greatly recovered. The ovaries contained immature and maturing oocytes, and some of them were under atretia at interval and final samplings.
Table 1. Percentage mortalities of eggs and larvae in control water and phenol solutions (first breeding)

\begin{tabular}{|c|c|c|c|c|c|c|}
\hline \multirow[b]{2}{*}{ Day } & \multicolumn{2}{|c|}{ Control } & \multicolumn{2}{|c|}{$2.2 \mathrm{ppm}$} & \multicolumn{2}{|c|}{$4.9 \mathrm{ppm}$} \\
\hline & A & B & A & $B$ & $A$ & $\mathrm{~B}$ \\
\hline 1 & 4 & 7 & 2 & 3 & 6 & 6 \\
\hline 2 & 21 & 20 & 32 & 26 & 21 & 32 \\
\hline 3 & 4 & 3 & 1 & 2 & 3 & 8 \\
\hline 4 & 0 & 0 & 0 & 0 & 0 & 0 \\
\hline 5 & 0 & 0 & 0 & 0 & 0 & 0 \\
\hline 6 & 4 & 0 & 4 & 0 & 4 & 4 \\
\hline 7 & 5 & 10 & 6 & 6 & 6 & 7 \\
\hline 8 & 5 & 6 & 8 & 11 & 21 & 22 \\
\hline 9 & 10 & 0 & 5 & 6 & 15 & 10 \\
\hline 10 & 4 & 4 & 4 & 5 & 10 & 6 \\
\hline 11 & 1 & 0 & 4 & 2 & 7 & 3 \\
\hline 12 & 2 & 4 & 4 & 3 & 7 & 2 \\
\hline 13 & 0 & 0 & 0 & 1 & - & - \\
\hline 14 & 0 & 0 & 0 & 0 & & \\
\hline 15 & 0 & 0 & 0 & 0 & & \\
\hline Total & $60 \%$ & $54 \%$ & $70 \%$ & $65 \%$ & $100 \%$ & $100 \%$ \\
\hline
\end{tabular}

$A$ and $B$ are duplicates of the same solution.

C) $2.2 \mathrm{ppm}$ phenol concentration. During the course of the experiment the phenol concentration ranged from 2.0 to $2.5 \mathrm{ppm}$ immediately after renewing and from 0.8 to $1.6 \mathrm{ppm}$ prior to renewing.

Under this regime the fish behaved almost similar to those of the control groups. The fish also showed good appetite. The average body weight at the end of experiment was $0.32 \mathrm{~g}$.

The blood cells showed different shapes and sizes in a few cases however, they were similar to the control in most cases. Histologically, in the interval and final samplings the condition of intestine, liver and kidney were nearly identical to those of the control. The epithelial layers of the gills in a few cases were slightly swollen.

Under this regime, spawnings were observed frequently. The spawnings interval ranged between 4-8 days during the course of experiment. Histologically, the ovaries contained oocytes at various maturation stages and a few of them were under atretia in the interval and final samplings. The atretic oocytes in the ovaries of the fish at $2.2 \mathrm{ppm}$ were quantitively less than those at 4.9 ppm.

\section{Experiment 2}

First breeding experiment. Larvae in the control, 2.2 , and $4.9 \mathrm{ppm}$ phenol solutions were hatched after 2-3 days. Eggs and larvae mortalities are shown in Table 1. The mortalities of 
Table 2. Percentage mortalities of eggs and larvae in the control and phenol solutions (second breeding)

\begin{tabular}{|c|c|c|c|c|c|c|c|c|}
\hline \multirow{2}{*}{ Day } & \multicolumn{2}{|c|}{ Control } & \multicolumn{3}{|c|}{$2.2 \mathrm{ppm}$} & \multicolumn{3}{|c|}{$4.9 \mathrm{ppm}$} \\
\hline & A & B & A & B & $C$ & A & B & $\mathrm{C}$ \\
\hline$\frac{1}{2}$ & $\begin{array}{r}35 \\
0\end{array}$ & $\begin{array}{r}30 \\
0\end{array}$ & $\begin{array}{r}40 \\
0\end{array}$ & $\begin{array}{r}45 \\
0\end{array}$ & $\begin{array}{r}43 \\
0\end{array}$ & $\begin{array}{r}60 \\
0\end{array}$ & $\begin{array}{r}75 \\
5\end{array}$ & $\begin{array}{r}50 \\
0\end{array}$ \\
\hline 3 & 0 & 0 & 0 & 0 & 0 & 0 & 0 & 0 \\
\hline 4 & 0 & 0 & 0 & 0 & 0 & 0 & 0 & 0 \\
\hline 5 & 20 & 15 & 5 & 15 & 10 & 30 & 10 & 20 \\
\hline 6 & 10 & 15 & 20 & 5 & 9 & 10 & 5 & 11 \\
\hline 7 & 0 & 0 & 5 & 2 & 1 & - & 5 & 2 \\
\hline 8 & 0 & 0 & 0 & 0 & 0 & & - & 0 \\
\hline 9 & 0 & 0 & 0 & 0 & 0 & & & 0 \\
\hline 10 & 0 & 0 & 0 & 0 & 0 & & & 0 \\
\hline Total & $65 \%$ & $60 \%$ & $70 \%$ & $67 \%$ & $63 \%$ & $100 \%$ & $100 \%$ & $83 \%$ \\
\hline
\end{tabular}

A. Eggs without wash were placed in the same concentration as their parental stock

B. Eggs after wash were placed in the same concentration as their parental stock

C. Eggs after wash were placed in the control water

the off-springs were maximum during the embryonic development and when the larvae commenced active feeding. All the larvae at $4.9 \mathrm{ppm}$ died after 12 days of exposure. At $2.2 \mathrm{ppm}, 30 \%$ and $35 \%$ of the A and B and at control, 40 and $46 \%$ of the $A$ and $B$ groups remained alive, respectively. The survived larvae grew successfully till the end of the experiment. The average body weights at $2.2 \mathrm{ppm}$ were 0.26 and $0.29 \mathrm{~g}$ for $\mathrm{A}$ and $\mathrm{B}$, and at controls they were 0.25 and $0.28 \mathrm{~g}$ for $\mathrm{A}$ and $\mathbf{B}$ groups, respectively.

Second breeding experiment. Eggs and larvae mortalities of control, 2.2 , and $4.9 \mathrm{ppm}$ groups are shown in Table 2. Eggs and larvae of A and B groups of $4.9 \mathrm{ppm}$ died within 7 days, while $17 \%$ of the larvae at $\mathrm{C}$ group survived till the end of the experiment. At $2.2 \mathrm{ppm} ; 30 \%$ of A, $33 \%$ of $\mathrm{B}$, and $37 \%$ of $\mathrm{C}$ group remained alive till the termination of the experiment. At the control experiment, $35 \%$ of $\mathrm{A}$ and $40 \%$ of $\mathrm{B}$ group survived. These larvae showed good appetide almost comparable to those of the control ones and their growth was successful.

The average body weight of $C$ group at $4.9 \mathrm{ppm}$ was $0.21 \mathrm{~g}$. At $2.2 \mathrm{ppm}$, the average body weights were $0.29,0.31$, and $0.30 \mathrm{~g}$ for $\mathrm{A}, \mathrm{B}$, and $\mathrm{C}$ groups, and at control groups they were 0.31 , and $0.30 \mathrm{~g}$ for A and B groups, respectively.

Histologically, the liver, kidney, intestine, gills, and hematologically the blood cells of the survived larvae were almost identical to those of the control groups in the first and second breedings.

\section{Discussion}

Zebrafish reacted to 24 and $4.9 \mathrm{ppm}$ phenol almost immediately after placement in these solutions. They swam wildly up and down, the movement of the mouth and gill opercles were violent, the fish tried to keep themselves near the surface of the water and gulped air. The abnormal behaviors at $24 \mathrm{ppm}$ were more severe and lasted longer than those at $4.9 \mathrm{ppm}$. These behaviors occurred due to the toxic effect of phenol as were stated in the acute tests. ${ }^{03}$ However, the fish behaved almost similarly to the control ones when were kept at $2.2 \mathrm{ppm}$.

Histologically, the fish exposed to the $24 \mathrm{ppm}$ showed severe damages to the gills, liver, kidney and intestine, and most fish died at $24 \mathrm{ppm}$ within few days. However, the extent of damages of these organs were slight at $4.9 \mathrm{ppm}$ and no fish died. As the degree of damages in the dead fish were greater than those in the survived fish, it may be stated that the cause of death is due to these damages, most possibly due to asphyxia. Furthermore, the physiologial changes of the liver and kidney could be also the cause of death as were stated in the acute tests. ${ }^{8)}$ At 2.2 ppm, there were not found any clear destructive histological changes in the gills, intestine, liver and kidney. It is suggested that the concentration of $2.2 \mathrm{ppm}$ is too low to cause damages to these organs.

At 24 ppm, 3 out of 9 fish of each duplicated group remained alive. These fish did not eat in the first 2 weeks though gradually commenced eating and till termination of the experiment the histological damages were greatly improved. The 
fish at $4.9 \mathrm{ppm}$ also showed better apparent and histological conditions at the termination as compared with the interval samplings. These phenomena may be due to the adaptation of the fish to the phenol toxicity. Adaptation presumably is related to the improvement of the liver in the process of detoxification of phenol as well as improvement of the kidney for removal of wastes from the body. Detoxification role of the liver has been described in other animals. ${ }^{1-14)}$ Since the number of disintegrated and deformed blood cells were not so distinctive at the end of the experiment, it might also indicate that the defensive reaction improved over the course of the phenol treatments and acted effectively against the toxic influence of phenol in zebrafish.

Spawning intervals of the parents at 4.9 and 2.2 ppm phenol solution were apt to be longer as compared to the control. The ovaries of 4.9 and $2.2 \mathrm{ppm}$ consisted oocytes in various maturational stages. Some of these oocytes were under atretia which their quantities were distinctly greater at 4.9 ppm than at $2.2 \mathrm{ppm}$. All the fish at $24 \mathrm{ppm}$ possessed only immature oocytes and no one spawned during the experiment. From these results it is obvious that the phenol toxicity is an essential cause of partial or total prevention of gonadal maturation in zebrafish.

In the first breeding, the off-springs (eggs and larvae) of $4.9 \mathrm{ppm}$ groups perished within 12 days (Table 1), though in the second breeding the offsprings died within 7 days (Table 2). It might suggested that the longer exposure of parents to the same phenol concentration causes reduction of the eggs qualities.

In the second breeding, the mortalities of the off springs of $4.9 \mathrm{ppm}$ were more than those of $2.2 \mathrm{ppm}$ when both groups were cultured at the control water (compare $\mathrm{C}$ groups of Table 2). These results indicate that the treatment of parental fish with higher phenol concentration cause more reduction of the eggs quantities.

In zebrafish, the least resistance to phenol was during embryonic development. In addition, actively feeding larvae were more sensitive than the yolk sac larvae. Similar reactions were observed in the bream. ${ }^{15}$ )

At $2.2 \mathrm{ppm}$, the cultures of eggs were successful. No distinet differences were observed between the behavior and histological pictures of the larvae which cultured at $2.2 \mathrm{ppm}$ and those of the control. Thus, the minimum concentration of phenol which cause damages to the off-springs survival rates exist between 2.2 and 4.9 ppm.

\section{References}

1) D. Stofen: Toxicology, 18, 187-195 (1973).

2) J. V. Hunter: Organic Compound in Aquatic Environment, Marcel Dekker, Inc. New York, 1971, pp. 51-94.

3) Environmental Protection Agency (EPA): Iterim Draft No. 1, Washington D. C., Government Printing Office 1977a, pp. 57.

4) G. A. Junclus, V. Lopez-Avila, and A. R. Hites: Environ. Sci. Tech., 12, 88-96 (1978).

5) P.W. Webb and J. R. Brett: Environ. Prot. Tech. Serv. EPA-R, 273-277 (1973).

6) L. Renberg: Anal. Chem., 46, 459-461 (1974).

7) D. W. M. Herbert: Ann. Appl. Biol., 50, 755777 (1962).

8) Q.H. Pickering and C. Henderson: J. Wat. Pollut. Control. Fed., 38, 1419-29 (1966a).

9) H. Razani, K. Nanba, and S. Murachi: Bull. Japan. Soc. Sci., 52, 1547-1552 (1986).

10) "Standard Methods for The Examination of Water, Sewage And Industrials Wastes, 14th ed, American Public Health Association (APHA), New York 1975 pp. 1193.

11) R. T. Williams: Detoxification Mechanisms, The Metabolism and Detoxification of Drugs, Toxic Substances and Other Organic Compound, Chaman and Hall, London, 1959, pp. 198.

12) Environmental Protection Agency (EPA): Interim Draft No. 1, Washington D. C. Government Printing Office 1977b, pp. 29.

13) Kobayashi, K, S. Kimura, and E. Shimizu: Bull. Japan. Soc. Sci., 43, 601-607 (1977).

14) R. H. Adamson and M. A. Guarino: Comp. Biochem. Physiol., 42A, 171-182 (1962).

15) V. M. Volodin: Tr. Inst. Biol. Vuntr. Akad. Nauk. Ussr., 24, 67-71 (1973). 